Owen, K. C., A. D. Melin, F. A. Campos, L. M. Fedigan, T. W. Gillespie, and D. J. Mennill. 2020. Bioacoustic analyses reveal that bird communities recover with forest succession in tropical dry forests. Avian Conservation and Ecology 15(1):25. https://doi.org/10.5751/ACE-01615-150125 Copyright (C) 2020 by the author(s). Published here under license by the Resilience Alliance.

Research Paper

\title{
Bioacoustic analyses reveal that bird communities recover with forest succession in tropical dry forests
}

\author{
Kiirsti C. Owen ${ }^{1}$, Amanda D. Melin ${ }^{2,3}$, Fernando A. Campos $^{4}$, Linda M. Fedigan ${ }^{2}$, Thomas W. Gillespie ${ }^{5}$ and Daniel J. Mennill $^{1}$ \\ ${ }^{1}$ Department of Integrative Biology, University of Windsor, ${ }^{2}$ Department of Anthropology and Archaeology, University of Calgary, \\ ${ }^{3}$ Alberta Children's Hospital Research Institute, University of Calgary, ${ }^{4}$ Department of Anthropology, University of Texas at San \\ Antonio, ${ }^{5}$ Department of Geography, University of California Los Angeles
}

\begin{abstract}
With expanding anthropogenic disturbances to forests around the world, forest restoration is increasingly important for bird conservation. Restoration monitoring is critical for understanding how birds respond to forest regeneration and for assessing the effectiveness of restoration efforts. Using bioacoustic monitoring, we recorded bird communities during both dry and wet seasons at 62 sites along a chronosequence of tropical dry forests in the Área de Conservación Guanacaste in Costa Rica. Tropical dry forests rank among the globe's most imperiled ecosystems, adding special urgency to their restoration and accompanying restoration monitoring. We found that bird species diversity, richness, and abundance increase with measures of forest maturity. Our results show that bird communities in regenerating areas become more similar to those of undisturbed areas as forests mature. This suggests that bird communities are recovering to predisturbed conditions in regenerating sites, and that maturing tropical dry forests are home to an increasingly diverse and abundant community of birds. We conducted an additional assessment, by sampling 30 locations using point-counts that were originally surveyed 23 years ago. We found that species richness and abundance were similar across this 23 -year interval, although bird community composition changed because several forest-specialist species were only detected in the later period. Our research reveals that the regenerating tropical dry forests of northwestern Costa Rica have recovered species richness and abundance levels and are currently undergoing a succession in community composition toward that of a primary tropical dry forest. Our study shows bird communities recovering in a nearly century-old chronosequence of regenerating forests.
\end{abstract}

\section{Des analyses bio-acoustiques révèlent que les populations aviaires se rétablissent avec la régénération forestière dans les forêts tropicales sèches}

RÉSUMÉ. Compte tenu du développement des perturbations anthropiques dans les forêts du monde entier, la reforestation est de plus en plus importante pour la conservation des oiseaux. La surveillance de la restauration des forêts est essentielle pour comprendre la manière dont les oiseaux réagissent à la régénération des forêts et pour évaluer l'efficacité des efforts de reforestation. Nous avons utilisé la surveillance bio-acoustique pour enregistrer les populations aviaires au cours de la saison sèche et de la saison humide sur 62 sites le long de la chronoséquence des forêts tropicales sèches dans l'Área de Conservación Guanacaste au Costa-Rica. Les forêts tropicales sèches font partie des écosystèmes les plus menacés de la planète, ce qui confère un caractère particulièrement urgent à leur restauration et à la surveillance de ces entreprises de reforestation. Nous avons constaté que la diversité, la richesse et l'abondance des espèces d'oiseaux augmentent avec les mesures de maturité des forêts. Nos résultats démontrent que les populations aviaires dans les zones de reforestation s'apparentent davantage à celles des zones non perturbées pendant la croissance des forêts. Cela semble indiquer que les populations d'oiseaux se rétablissent à leurs niveaux préalables aux perturbations dans les sites de reforestation, et que les forêts tropicales sèches en cours de maturation abritent une population aviaire de plus en plus diverse et abondante. Nous avons procédé à une évaluation supplémentaire sur un échantillon de 30 sites à l'aide d'un système de points que nous avions initialement utilisé il y a 23 ans. Cela nous a permis de constater que la richesse et l'abondance des espèces étaient restées similaires au terme de cette période de 23 ans, bien que la composition des populations ait changé, puisque plusieurs espèces d'oiseaux forestiers n'ont été détectées que sur la fin de la période. Notre recherche révèle que la régénération des forêts tropicales sèches du nord-ouest du Costa-Rica a permis de rétablir les niveaux de richesse et d'abondance des espèces et que plusieurs types de populations aviaires se sont succédées pour revenir à celle d'une forêt tropicale sèche primaire. Notre étude démontre que les populations aviaires se reconstituent au cours d'une chronoséquence de près d'un siècle de reforestation.

Key Words: bioacoustics; biodiversity; bird species recovery; community composition; conservation; forest restoration; neotropical bird communities; passive acoustic monitoring; tropical dry forest

\section{INTRODUCTION}

The impacts of environmental change on wildlife are well documented, with overwhelming evidence demonstrating that habitat loss and fragmentation have negative impacts on biodiversity (Brooks et al. 2002, Fahrig 2003). However, some forms of habitat change, such as habitat restoration or forest regeneration, can result in significant benefits for wildlife, especially in areas where some of the original forest has been 
removed (Rey-Benayas et al. 2009, Edwards et al. 2017). Although restoration is emerging as an important approach to counteract the negative effects of habitat loss and degradation (Montoya et al. 2012), restoration monitoring is given less attention (Wortley et al. 2013). Without adequate monitoring of wildlife responses, we cannot assess whether restoration efforts are beneficial to wildlife (Block et al. 2001, DeLuca et al. 2010). Therefore, it is crucial that restoration is accompanied by wildlife monitoring to understanding whether restoration efforts are successful.

Previous investigations of habitat restoration and forest regeneration have shown that monitoring can help to guide good conservation practice (Wortley et al. 2013). For example, in northern Sweden, monitoring efforts revealed that bird diversity varied between two boreal forest restoration methods; sites with prescribed burns showed higher bird species richness and abundance, whereas sites with artificial gap creation showed no change (Versluijs et al. 2017). In the northwestern United States, monitoring efforts showed that an endangered butterfly species successfully established itself in a recovering forest, but indicated that larval resources were insufficient for long-term recovery (Schultz 2001). These examples highlight the importance of monitoring restoration programs to inform future conservation efforts.

In northwestern Costa Rica, an ambitious effort in ecological restoration began four decades ago, with the goal of protecting remaining patches of primary tropical dry forest and restoring the land surrounding these areas to facilitate forest maturation (Allen 2001, Janzen and Hallwachs 2020). These forests have been subject to centuries of anthropogenic disturbance where most of the original forests were logged, burned, and cleared for ranching and agriculture (Moline 1999). Since the 1980s, the government and people of Costa Rica, with support from the international community, have endeavored to regrow parcels of tropical dry forest, thereby reconnecting the remnant patches of primary mature forest (Allen 2001). This significant undertaking resulted in the creation of a new protected area called the Área de Conservación Guanacaste, which encompasses over 169,000 hectares (Janzen and Hallwachs 2020). Restoration has largely been through methods that promote natural regeneration, including fire suppression and cattle removal, although tree planting of locally grown native species has also occurred (Moline 1999, Allen 2001). Today, the conservation area represents a mosaic of primary and secondary forests ranging in age from less than 1 year to over 400 years old (Janzen 1988a, Janzen and Hallwachs 2020). The few remaining patches of primary forest in this mosaic are considered reference sites for restoration efforts in the tropical dry forest areas of the Guanacaste province (Janzen 1988b). Recent research in the Área de Conservación Guanacaste suggests that secondary tropical dry forests have functional traits and vegetative structure similar to that of old growth forests within 100 years of successional regrowth (Buzzard et al. 2016). Vegetation features change with forest regeneration, with plant species richness and above-ground biomass increasing with forest age, and with maturing forests exhibiting different tree species composition (Buzzard et al. 2016). These results suggest that efforts to restore tropical dry forests in the Área de Conservación Guanacaste are promoting vegetation conditions similar to predisturbed states.
Tropical dry forests are considered to be one of the most imperiled tropical ecosystems in the world (Janzen 1988a, Miles et al. 2006). These forests experience extreme seasonality with pronounced dry and wet seasons that each span approximately six months of the year (Janzen 1983a, Melin et al. 2014). Plant and animal species living in these forests have adapted to the extreme conditions of tropical dry forests, with some species being endemic to tropical dry forests, and others exhibiting unique life histories or behaviors not seen in nearby rainforests (Janzen 1988b). In Guanacaste, annual rainfall varies between 800 and $2600 \mathrm{~mm}$, with the overwhelming majority of rainfall occurring during the wet season (approximately May to November; Moline 1999). The end of the dry season is characterized by drought and high temperatures, and most trees drop their leaves to conserve water (Moline 1999). In the dry season, only late successional forests retain a closed canopy cover that exceeds 50\% (Kalacska et al. 2005). For this reason, many animals move into patches of mature forest during the dry season where the microclimate is cooler and moister than surrounding forests (Janzen 1988b). Even animals living within the mature tropical dry forests face reduced survival in the heat and desiccation of the late dry season, and this pressure is becoming more pronounced with global climate change (Woodworth et al. 2018).

More generally, a meta-analysis on tropical bird community recovery in regenerating forests found encouraging results; species richness and abundance can recover relatively quickly (within decades), although full recovery of community composition can take centuries (Dunn 2004). Most studies of bird community responses to environmental changes have used traditional methods for collecting information on avian biodiversity, e.g., point-count surveys or spot mapping (e.g., Pejchar et al. 2018, Frishkoff and Karp 2019, Roels et al. 2019, Santillán et al. 2020). Bioacoustic monitoring is an emerging tool for studying animals on the basis of their vocalizations, and has proven to be very effective for monitoring bird communities (Burivalova et al. 2019, Teixeira et al. 2019). Bioacoustic surveys can increase the amount of data collected while creating a permanent record of these data and using fewer resources (Shonfield and Bayne 2017, Teixeira et al. 2019). Furthermore, there is evidence to suggest that passive acoustic monitoring performs similarly to traditional survey methods (Darras et al. 2018a). By using a bioacoustic approach to study changes in bird communities in recovering neotropical forests, we stand to develop a deeper understanding of the consequences of conservation actions on avian biodiversity.

We used passive acoustic monitoring to study bird communities in the regenerating forests of the Área de Conservación Guanacaste. We tested the hypothesis that bird communities change with the successional state of the forest (Catterall et al. 2012, Frishkoff and Karp 2019). We predicted that as forests increase in maturity and complexity, bird species diversity and bird abundance would change to resemble diversity and abundance features found in primary forests (Latja et al. 2016). We also predicted that different assemblages of birds would exist in forests of different ages, and that these assemblages would continue to become more similar to those found in primary forests over time. Given that the tropical dry forest ecosystem is defined by a dramatic transition between the dry and wet season, we were also interested in quantifying bird communities in both dry and wet seasons. We predicted that season would influence bird 
diversity, abundance, and composition, which would be reflected by differences in these variables between dry and wet seasons.

\section{METHODS}

\section{Study sites}

We monitored bird diversity and abundance using acoustic recordings that we collected between April and July of 2018 and 2019 in the Área de Conservación Guanacaste in northwestern Costa Rica $\left(10^{\circ} 52^{\prime} \mathrm{N}, 85^{\circ} 36^{\prime} \mathrm{W}\right.$; Fig. 1). These recordings coincided with the end of the dry season and the beginning of the wet season (typically mid-May), a time period when most birds in this ecosystem initiate breeding. We chose 62 sites within the Área de Conservación Guanacaste to collect recordings (Fig. 1, Appendix 1). The regenerating sites in our study area have been subject to continued anthropogenic disturbance in the form of ranching and farming for over four centuries, and each site only began the regeneration process when it was given protected status at different times in the past century (Allen 2001, Janzen and Hallwachs 2020). Staff of the Área de Conservación Guanacaste continue to use passive methods, such as fire suppression, cattle exclusion, and prohibition of logging, to promote natural regeneration of these forests (Allen 2001, Janzen and Hallwachs 2020). In both 2018 and 2019, we sampled bird communities in 13 sites that were part of a previous vegetation study by Buzzard et al. (2016). We sampled 49 additional sites within Sector Santa Rosa over those same two years $(n=31$ sites in $2018 ; n=18$ sites in 2019; details below). Within the tropical dry forests in the Área de Conservación Guanacaste, these sites comprise a chronosequence, a collection of forest sites that represent the different successional stages (Chazdon et al. 2007, Quesada et al. 2009). When long-term data do not exist to evaluate restoration success, a chronosequence can be used in place of temporal data (Chazdon et al. 2007). Our chronosequence included sites at different stages of the regeneration process, and also primary forest sites that we considered to be mature reference sites. Information on the age of all 62 sites was provided by the scientific director of the Área de Conservación Guanacaste, R. Blanco. We considered all sites with no disturbance in the last 100 years to be reference sites, i.e., mature primary forest, whereas all of the regenerating sites were deforested within the last 100 years (range: 5-70 years; R. Blanco, personal communication). Although the mature sites have never been cleared, and trees that are many hundreds of years old are commonplace in those sites, mahogany trees were selectively removed in the 1940s (Janzen 1983b).

\section{Vegetation measurements}

Vegetation measurements came from two different datasets. In 2016 and 2017, vegetation transect surveys were completed in Sector Santa Rosa as part of a concurrent research project (Orkin et al. 2019). We included 49 of these survey sites to collect acoustic recordings of birds, choosing sites that were at least $150 \mathrm{~m}$ apart and that together created a representative sample of different aged forests (from 5 to more than 100 years old). Vegetation data from these surveys included total basal area, tree species richness, and tree abundance. In 2010, Buzzard et al. (2016) collected vegetation data at 13 sites, which represented different ages of tropical dry forests ranging from 20 years to $>100$ years. From these vegetation data, we looked at basal area, tree species richness, and tree abundance.
Fig. 1. Maps of the Área de Conservación Guanacaste, Costa Rica, showing the location of 62 sites monitored with autonomous recording units in 2018 and 2019, as well as the area where point counts were conducted in 1996 and 2019 (orange shaded rectangle). Left map shows the more northerly sites, and right map shows the more southerly sites (these regions are separated by approximately $1 \mathrm{~km}$ ). White lines represent roads. Red arrow in the inset map shows the location of the study site in Central America.

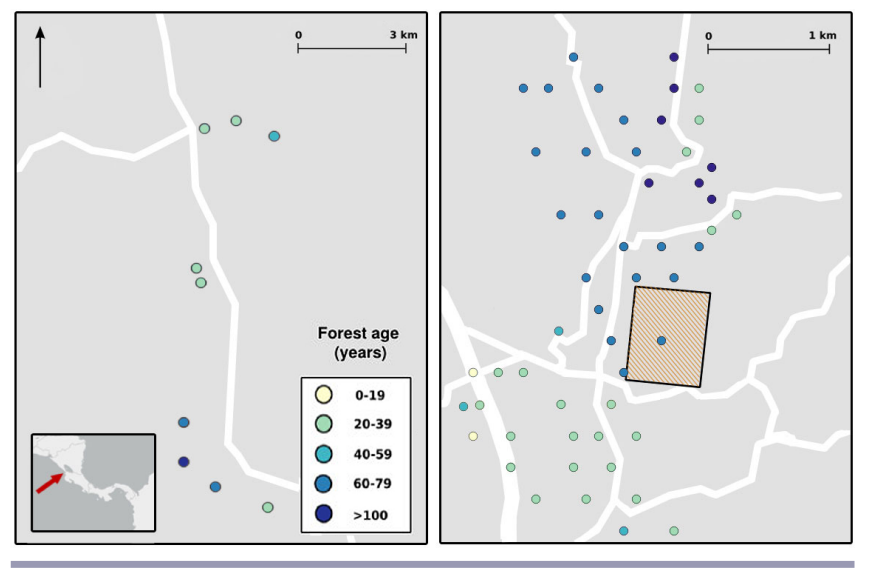

Canopy height and canopy cover data were not included in either of the vegetation datasets, yet canopy height and canopy cover are recognized to be important for birds (Matlock and Edwards 2006). Therefore, in 2019, we collected canopy height and cover measurements at $n=31$ sites that were recorded that year. We measured canopy height based on a single representative tree using a clinometer (Matlock and Edwards 2006). We collected canopy cover measurements using wide-angle photography at each site during both the dry and wet seasons. We obtained a measurement of percent cover using Gap Light Analyzer imaging software (Frazer et al. 1999, Kalacska et al. 2005) and we calculated the percent cover across four photos per site to obtain a single estimate for each site.

\section{Bird community measurements}

We collected recordings using autonomous recording units (models Song Meter SM1 and SM2+; these models use the same microphones and hardware; Wildlife Acoustics Inc., Maynard, MA). We used six recorders and moved them to different recording sites on subsequent days. Each recorder had an equally likely chance of being used at regenerating sites and reference sites. We used one recorder per site and recorded multiple sites per day. Recorders were placed at a height of approximately 1.5 meter from the ground. All 62 sites were recorded in the same location (Appendix 1) at two different time periods: in the dry season, and then again shortly after the onset of heavy rains (the first sustained rainfall was 16 May in 2018 and 13 May in 2019). Resampling sites during both dry and wet seasons allowed for a comparison of bird vocal activity at different sites during both seasons. We recorded sites continuously for at least one day, and we left recorders in place at sites for an additional day of recording if heavy rain or wind interrupted the recording during the dawn chorus. All recordings are archived in the Mennill Sound Analysis Laboratory. 


\section{Bird community recording analyses}

We evaluated vocal activity from 150 recordings (62 sites, each recorded in the dry and wet seasons, some in both years; see Appendix I). We analyzed 10-minute samples from 0600 to 0610 $\mathrm{h}$, which coincides with a peak in avian vocal activity. Other studies, including studies in this ecosystem, have found that bird activity peaks around sunrise or in the hour following sunrise (Robbins 1981, Mennill and Vehrencamp 2005, Baldo and Mennill 2011, Koloff and Mennill 2013, Demko and Mennill 2019). Sunrise in Sector Santa Rosa from April to July occurs at approximately $0515 \mathrm{~h}$. Field recordings were listened to and manually scanned by a single skilled observer (KCO) who visualized recordings as stereo sound spectrograms in Audacity (v2.2, Audacity Team 2018). To aid in species identification, we used online resources, such as Xeno-Canto (http://www.xenocanto.org), the Macaulay Library (https://www.macaulaylibrary. org), as well as a library of recordings that our research team has developed over the last 17 years of working in this environment. We ascribed all vocalizations to species whenever possible. In many cases it was obvious that there were multiple individuals of a single species within a recording because of overlapping songs or the position of the vocalization relative to the stereo microphones; we conservatively calculated abundance using the position of birds relative to the microphones and overlapping songs as indicators of multiple individuals (Pillay et al. 2019). We included only resident species in our analyses, and removed any passage migrants (see Results). Given that we were interested in understanding how birds use forest sites of different ages, we chose to remove all parrots and parakeets from our analyses because they were consistently detected while flying over our autonomous recording units rather than landing within the recording sites.

\section{Comparison of bird communities across decades}

In addition to assessing bird communities along a chronosequence of tropical dry forest sites, we also sampled 30 sites in Sector Santa Rosa that were surveyed originally in 1996 (Gillespie 2000). These forests were 40-60 years old at the time of the 1996 survey (Gillespie 2000, Gillespie and Walter 2001), and 60-80 years old at the time of the 2019 survey. In early to midJune of 1996, a single observer (TWG) conducted 10-minute point-count surveys at 30 sites in a grid that was approximately 500 meters (east-west) by 600 meters (north-south) with $100-150$ meters between each point count station (Gillespie 2000). This observer surveyed between 0530 and $0800 \mathrm{~h}$ for 10 minutes during fair weather days and included detections of all bird species within a 25 meter radius (Ralph et al. 1995, Gillespie 2000, Gillespie and Walter 2001). We replicated these point count surveys in the same forest in June 2019. Two observers (KCO and a field assistant) visited 30 sites within three days in mid-June approximately one month after the beginning of the wet season. Both observers completed practice point count surveys together prior to the survey days to ensure they had similar abilities in bird identification and distance estimates. Seasonal timing was similar between the two sampling years with the onset of heavy rains arriving in mid-May in both 1996 and 2019. We documented all birds detected during the surveys, however, for consistency with our automated recordings, we removed passage migrants and flyover species from final analyses. For consistency with the 1996 surveys, we only included birds detected within 25 meters.

\section{Statistical analyses}

We conducted all analyses in R (v3.6.1, R Development Core Team 2019). To test relationships among forest maturity, season, and bird biodiversity, we first created a Pearson's correlation matrix using R package "PerformanceAnalytics" (Peterson et al. 2020). Four habitat variables were positively correlated with forest age $(r>0.35, p<0.001)$ including tree species richness, total basal area, canopy height, and canopy cover, while tree abundance was negatively correlated with forest age $(r=-0.34, p<0.0001)$. Additionally, during model selection, forest age was the only habitat variable that consistently showed a relationship with our bird response variables across all models. Therefore, for ease of interpretation we chose to use forest age to represent forest maturity in all of our final analyses.

We chose three variables related to bird biodiversity to use in our analyses: estimated total species richness (the Chaol estimator; Chao 1984, Latta et al. 2018), effective number of species (Jost 2006, Latta et al. 2018), and observed bird abundance. Estimated total species richness was calculated using the function estimate $R$ in R package "vegan" (Oksanen et al. 2019). The Chaol estimator ( $S=$ distinct species, $S_{\text {chaol }}=$ estimated number of species, $S_{\text {obs }}=$ observed species, $n_{1}$ and $n_{2}=$ samples 1 and $2, p_{i}=$ relative abundance of species $i$ ) provides a lower bound estimate but has been shown to be a good estimator of true species richness (Walther and Moore 2005).

$$
S_{\text {Chao } 1}=S_{o b s}+\frac{n_{1}^{2}}{2\left(n_{2}+1\right)}-\frac{n_{1} n_{2}}{2\left(n_{2}+1\right)^{2}}
$$

We log transformed the total species richness values to correct for non-normality. We obtained Shannon diversity values for each survey using the function diversity in R package "vegan" (Oksanen et al. 2019). We used these values to calculate a diversity estimate accounting for species evenness called "effective number of species," by exponentiating Shannon entropy $(D=$ diversity estimate, $S=$ distinct species, $p_{i}=$ relative abundance of species $i$, (Jost 2006, Latta et al. 2018).

$$
{ }^{1} D=\exp \left(-\sum_{i=1}^{S} p_{i} \ln \left(p_{i}\right)\right)
$$

Observed bird abundance was simply the number of individuals identified on each recording.

To understand how bird communities respond to increasing forest maturity and season, we created linear mixed models using the $\mathrm{R}$ package "Ime4" (Bates et al. 2015). In our models, we used season and forest age as fixed effects and we included the interaction between the two. Our models included both site identity and year, with a nested effect of ordinal day, as random effects. For the purpose of our linear mixed models, we square root transformed observed bird abundance, which lessens the influence of the most abundant species (Latja et al. 2016). We visually assessed our data for normality and homoscedasticity in $\mathrm{R}$. We calculated marginal and conditional $R^{2}$ values for each of our models using rsquared in R package "piecewiseSEM" (Table 1; Lefcheck 2016), and pvalues using R package "ImerTest" (Kuznetova et al. 2017). Additionally, to examine differences in our response variables by season without the influence of forest age, we used paired t-tests to compare bird diversity and abundance in the dry versus wet 
Table 1. Results from linear mixed effects models with fixed effects of forest age and season, as well as the interaction between these two variables, on features of the bird community the Área de Conservación Guanacaste, Costa Rica. Random effects of site and day nested within year are included in the model. Response variables include total species richness, effective number of species, observed bird abundance (square root transformed), and percent similarity to reference community. Marginal and conditional $\mathrm{R}^{2}$ values are provided for each model.

\begin{tabular}{|c|c|c|c|c|c|}
\hline Response variable & Fixed effects & Estimate & $\mathrm{SE}$ & $t$ & $P$ \\
\hline Total species richness & Intercept & 14.4 & 1.6 & 9.1 & $<0.001$ \\
\hline $\mathrm{R}^{2}=0.27$ & Forest age & 0.2 & 0.03 & 5.7 & $<0.001$ \\
\hline $\mathrm{R}_{\mathrm{c}}^{2^{\mathrm{m}}}=0.45$ & Season & 1.1 & 2.6 & 0.3 & 0.78 \\
\hline- & Forest age $\times$ season & 0.07 & 0.04 & 1.5 & 0.14 \\
\hline Effective number of species & Intercept & 10.1 & 0.7 & 14.7 & $<0.001$ \\
\hline $\mathrm{R}^{2}=0.22$ & Forest age & 0.06 & 0.01 & 5.3 & $<0.001$ \\
\hline $\mathrm{R}_{\mathrm{c}}^{2^{\mathrm{m}}}=0.50$ & Season & 1.9 & 1.1 & 1.7 & 0.09 \\
\hline- & Forest age $\times$ season & -0.01 & 0.02 & -0.59 & 0.56 \\
\hline $\begin{array}{l}\text { Observed bird abundance } \\
\text { (square root transformed) }\end{array}$ & Intercept & 4.6 & 0.1 & 33.9 & $<0.001$ \\
\hline $\mathrm{R}^{2^{*}}=0.20$ & Forest age & 0.01 & 0.002 & 5.1 & $<0.001$ \\
\hline $\mathrm{R}_{\mathrm{c}}^{2^{\mathrm{m}}}=0.55$ & Season & 0.2 & 0.2 & 1.2 & 0.25 \\
\hline- & Forest age $\times$ season & -0.001 & 0.004 & -0.4 & 0.73 \\
\hline $\begin{array}{l}\text { Percent similarity to } \\
\text { reference community }\end{array}$ & Intercept & 24.8 & 2.6 & 9.6 & $<0.001$ \\
\hline $\mathrm{R}^{2} \mathrm{~m}=0.40$ & Forest age & 0.4 & 0.5 & 6.7 & $<0.001$ \\
\hline $\mathrm{R}_{\mathrm{c}}^{2^{\mathrm{II}}}=0.79$ & Season & 2.1 & 2.5 & 0.8 & 0.38 \\
\hline- & Forest age $\times$ season & 0.02 & 0.05 & 0.3 & 0.74 \\
\hline
\end{tabular}

seasons (with data from both years pooled for the sites that were sampled in both 2018 and 2019).

To compare community composition of regenerating forests (i.e., sites $<100$ years old) to our reference forests (i.e., sites $>100$ years old) we pooled species lists to create a total count of the number of each species across all surveys in reference forests during both seasons, and then accounted for sampling effort by dividing the counts of each species by the number of surveys $(n=18)$. We used the pooled species list to represent our reference community to compare to bird communities in the regenerating sites. We calculated Bray-Curtis dissimilarity values using the function vegdist in package "vegan" (Oksanen et al. 2019) for all 132 surveys in regenerating sites as a percent difference from the reference community. We subtracted these from one, and converted to a percentage, to obtain percent similarity values (i.e., Sørenson similarity index). We also calculated percent similarity scores for all 18 surveys in reference sites to examine variability within the reference forests. To answer our question of whether bird communities in regenerating forests are becoming more similar to those in our reference forests, we used linear mixed models to examine the relationship between forest age, season, and percent similarity to reference forests.

To evaluate differences between point counts conducted in 1996 and 2019, we compared species lists between the two years. Data from 1996 exist as total counts for species and individuals for all 30 sites combined, therefore, we compared counts of species from 1996 and 2019 as an observational analysis. As in other studies using point-count surveys, we excluded passage migrants and highly mobile species, i.e., parrots that were detected flying over the forest canopy, from our total species lists (Edwards et al. 2017, Darras et al. 2018b).

\section{RESULTS}

\section{Biodiversity assessments from automated recordings}

We recorded a total of 4884 individuals and 84 identifiable bird species across 62 sites in the tropical dry forests of Guanacaste, Costa Rica. We detected 2533 individuals of 77 species during the dry season, and 2351 individuals of 75 species during the wet season. We excluded two detections of passage migrants (one Swainson's Thrush, Catharus ustulatus, and one Yellow Warbler, Setophaga petechia), and we excluded 575 detections of parrots and parakeets detected flying over the recording sites (all detections are provided in Appendix 2). Any sounds that were not identified to species were also removed from our analyses $(n=$ 124). This resulted in a final count of 4183 individuals of 77 species included in our final analyses.

\section{Bird community recovery by forest age}

We found that total species richness, effective number of species, and observed bird abundance were positively related to forest maturity (Table 1, Fig. 2), such that older forests had higher species richness, diversity, and abundance. We found that communities in regenerating sites showed $18.5-58.9 \%$ similarity to the reference community, and that communities within individual reference sites used to create the reference community showed $49.1-62.4 \%$ similarity to the overall reference community. We found a positive relationship between percent similarity to the reference community and forest age (Table 1, Fig. 3), such that bird communities became more similar to the reference community with increasing forest age. We did not find a relationship between percent similarity to reference community and season, nor an interaction between season and age (Table 1). 
Fig. 2. (a) Estimated total species richness (Chao1), (b) effective number of species, and (c) observed bird abundance versus forest age at 62 sites sampled in the Área de Conservación Guanacaste, Costa Rica. References sites are denoted here as $>$ 100 years. Lines represent best fit based on linear mixed effect models of each bird response variable by forest age (excluding $>100$ year old forests) and season with $95 \%$ confidence intervals. Sites sampled in the dry season are shaded orange, and sites sampled in the wet season are shaded blue. All dryseason points are shifted one value to the left, and all wetseason points are shifted one value to the right, to reduce the number of overlapping points.

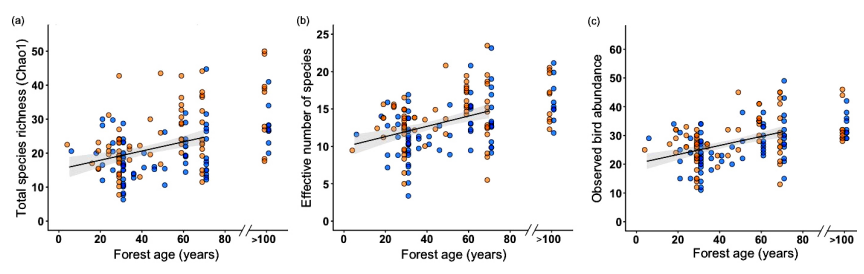

Fig. 3. Percent similarity between bird communities in each site compared to the reference community (pooled data from sites $>$ 100 years old) in Área de Conservación Guanacaste, Costa Rica. Line represents best fit based on linear mixed effects model of percent similarity by age of regenerating forest and season with $95 \%$ confidence intervals. Sites sampled in the dry season are shaded orange, and sites sampled in the wet season are shaded blue. All dry-season points are shifted one value to the left, and all wet-season points are shifted one value to the right, to reduce the number of overlapping points.

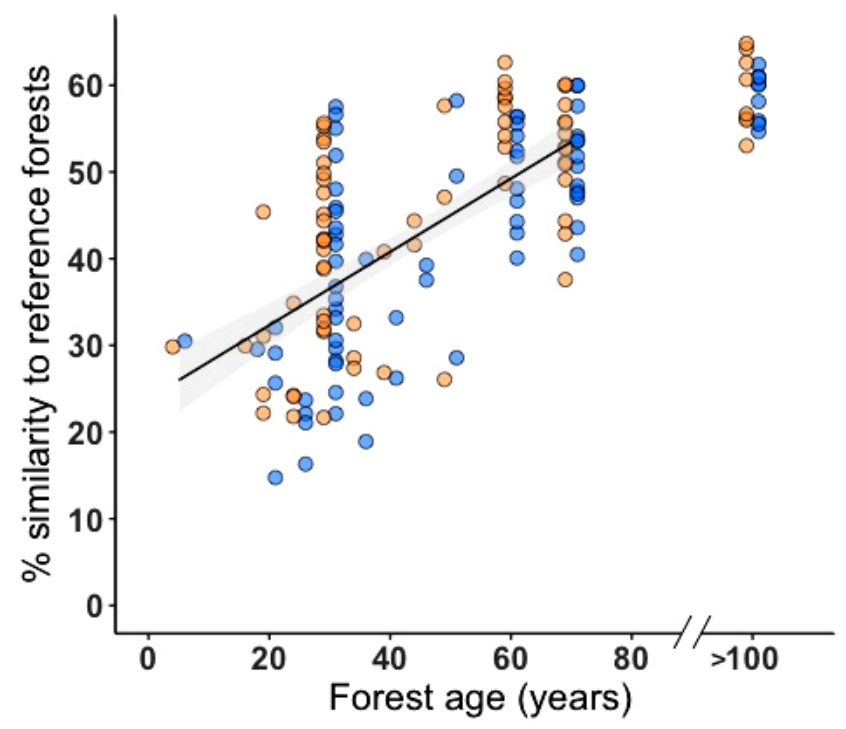

Biodiversity assessments in different seasons

We found that total species richness was higher in the dry season than the wet season (Fig. 4a; paired t-test: $t=3.9, d f=74, p=$ $0.0002)$. Similarly, effective number of species was also higher in the dry season than the wet season (Fig. $4 \mathrm{~b} ; t=3.1, d f=74, p=$ $0.003)$. Finally, we found that observed bird abundance was also higher in the dry season than the wet season (Fig. $4 \mathrm{c} ; t=-2.1, d f$ $=74, p=0.041$ ). Additionally, we found that effective number of species was related to season in our mixed model (Table 1), where the dry season exhibited greater bird diversity. We found no other relationships with season, and the interaction terms between forest age and season did not show a relationship with any of our measures of biodiversity (Table 1).

Fig. 4. (a) Estimated total species richness (Chaol estimator), (b) effective number of species, and (c) observed bird abundance in both dry season (orange) and wet season (blue) for birds in the Área de Conservación Guanacaste, Costa Rica. Data are shown both as box plots (central line shows the median, box boundaries represent the interquartile range; whiskers show the interquartile range multiplied by 1.5 with any values beyond these limits represented as dots) with the raw data shown beside the box plots.
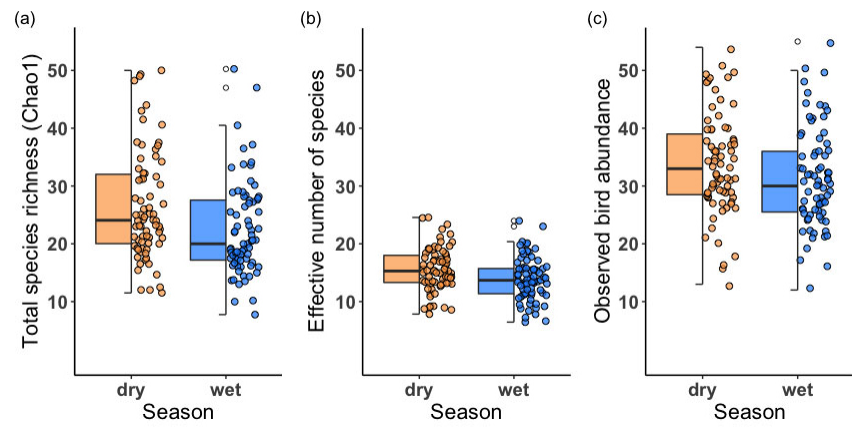

\section{Comparison of bird communities across decades}

In June 1996, 267 individuals of 37 species were detected during fixed-radius point-count surveys (Gillespie 2000). In June 2019, 238 individuals of 35 species were detected in the same area, suggesting similar species richness and abundance across a 23 year interval. Although species and individual counts between the 1996 and 2019 surveys were similar, we did notice changes in community composition. Several species associated with open and young forest habitats were present in 1996 surveys but absent from 2019 surveys, including White-throated Magpie-Jay (Calocitta formosa), Hoffmann's Woodpecker (Melanerpes hoffmannii), and White-lored Gnatcatcher (Polioptila albiloris). Conversely, several species associated with mature forest habitats were absent or rare in 1996 surveys but present or abundant in the 2019 surveys, including Great Curassow (Crax rubra), Lesser Greenlet (Pachysylvia decurtata), and Yellow-olive Flycatcher (Tolmomyias sulphurescens; see Appendix 3 for counts from 1996 and 2019).

\section{DISCUSSION}

Using automated recordings of bird vocalizations to assess avian biodiversity in neotropical dry forests, we found that bird species richness, diversity, and abundance increased as regenerating forests became more mature. However, even the oldest regenerating sites in our study (approximately 70 to 80 years old), 
still had lower total species richness, effective number of species, and observed abundance compared to the mature reference sites. This suggests that while bird biodiversity is recovering as neotropical forests regenerate, additional time is required before forest patches fully recover to predisturbance levels. The results from our point-count survey comparison showed minimal change in richness and abundance between surveys conducted 23 years apart. Overall, our results are consistent with the prediction that bird biodiversity increases with increasing forest age, although the relationship was not perfectly linear, suggesting that richness and abundance have the highest increase in the first few decades after regeneration begins, as has been observed in previous studies (Dunn 2004, Pejchar et al. 2018). Although some of our sampling locations exhibited richness and abundance levels similar to those observed in our mature reference sites, many younger regenerating sites will still require many decades to reach richness and abundance levels similar to our mature reference sites.

Our results show that bird communities in older regenerating sites became more similar to those in our reference forests, suggesting that community composition is recovering in regenerating forests. We also observed differences in community composition between the two point-count survey years, further supporting our hypothesis that different species use regenerating forests of different ages. We observed some overlap in community composition similarity values between regenerating forests and reference forests when comparing them to the reference community, suggesting that older regenerating sites may be recovering species composition to resemble primary forest communities. The high variability in similarity values within reference communities makes it challenging to evaluate the community composition recovery progress. These results follow similar conclusions from prior work on regenerating forest communities, where bird community composition was expected to take more than a century to fully recover (Shankar Raman et al. 1998, Dunn 2004). Specific to our study area, the complete recovery of these forests, i.e., including biotic and abiotic components, is a process that has been argued to require centuries (Allen 1988, Janzen 1988a). It could take equally long for bird communities to follow suit. Composition of wildlife communities is an important element in the recovery of an ecosystem. The health and integrity of an ecosystem depend not only on the number of species and individuals living in the ecosystem, but also on which species it contains (Sekercioglu 2012, Rempel et al. 2016). For a restored ecosystem to have ecological integrity, it must be able to support a community of species similar to that of undisturbed ecosystems (Karr and Dudley 1981, Carignan and Villard 2002).

Our results provide some interesting examples of how community composition changes with increasing forest age. Several species were detected in our youngest sites but did not occur in surveys from forests greater than 40 years old. These included Crested Bobwhite (Colinus cristatus), Double-striped Thick-knee (Burhinus bistriatus), Gray-crowned Yellowthroat (Geothlypis poliocephala), Lesser Ground-cuckoo (Morococcyx erythropygus), and Plain Chachalaca (Ortalis vetula). Similarly, many species were only detected in more mature regenerating sites ( $>40$ years old), including Long-billed Gnatwren (Ramphocaenus melanurus), Rufous-and-white Wren (Thryophilus rufalbus), Royal Flycatcher (Onychorhynchus coronatus), and Stub-tailed Spadebill (Platyrinchus cancrominus). One species, the Great Curassow, was only detected in our oldest regenerating sites $(\sim 70-80$ years old) and our reference sites ( $>100$ years old). This species is considered a forest specialist and is listed by the International Union for the Conservation of Nature as vulnerable (BirdLife International 2016). Interestingly, no Great Curassows were detected in the 1996 point-count surveys, whereas eight individuals were detected in the 2019 surveys in the same area. This is an encouraging example of a forest specialist species using an older regenerating forest as it begins to resemble a mature forest. These examples further illustrate that restoration efforts in the Área de Conservación Guanacaste are promoting the return of forests and bird communities to their predisturbed states. Our point count surveys were completed by different researchers in 1996 and 2019, and it is possible that variation in the detection and identification abilities of the researchers contributed to the differences we observed. However, given that all of the researchers involved had extensive experience with the vocalizations of birds in this region, we make the assumption that observer effects did not have a significant impact on our results. Using bioacoustic surveys instead of traditional in-person surveys in future research would reduce any observer effects (Campbell and Francis 2011).

We predicted that season would influence how bird communities use tropical dry forests, and in support of this prediction, we detected more birds in the dry season than the wet season. However, we did not find support for the idea that birds use mature forests as refugia in the dry season because there was no interaction between forest age and season in our models. These results may reflect a change in vocal behavior of birds between the two seasons. Many birds time their breeding activities so that they are feeding young when resource availability is high, which means breeding commences at the onset of the wet season in this habitat (Janzen 1983a). It is possible then that birds become more vocal toward the end of the dry season as they begin to defend territories, find mates, and build nests (Janzen 1983a), thus becoming easier to detect by automated recorders. Season may also affect detection rates if song transmission is influenced by changes in vegetation, possibly due to higher leaf density in the wet season. Because of our observed differences in detection rates between dry and wet seasons, we recommend that future research collecting bioacoustic data in tropical dry forests consider how season might influence vocal and breeding behavior in their species or communities of interest. Collecting recordings at other times of year, including the early dry season and late wet season, might help to further reduce seasonal biases. In addition to differences in detection rates, it is also possible that changes in community composition could arise from local movements of animals within our study area or movements to other ecosystems such as nearby rainforests or cloud forests. Although we removed long-distance migrants from our analyses, some dry forest animals are known to move between different areas in our study area to take advantage of different resources such as moist and cool refuges or fruiting trees (Janzen 1988a, Moline 1999). Although our results suggest a difference in bird vocalizations between dry and wet seasons, we have not determined whether these results reflect changes in detection rates or changes in community composition. Future research might consider using occupancy models with bioacoustic data to determine the differences between detection rates and community composition to address this ambiguity. 
Our bioacoustic surveys reveal that species richness, abundance, and community composition change as forests mature. Similarly, our point count surveys reveal that more forest specialist species and fewer open habitat species are present when forests mature. Many studies have highlighted the benefits of bioacoustic surveys over traditional methods (Celis-Murillo et al. 2012, Darras et al. $2018 a$ ), including the ability to review recordings as many times as necessary (Shonfield and Bayne 2017). With continued improvements in bird recognition software, these types of surveys will likely become increasingly efficient and popular in wildlife monitoring. Future research might consider pairing acoustic surveys with other emerging tools such as remote sensing. Comparing biodiversity data from regenerating forests over time presents a singular opportunity to understand how wildlife respond to habitat change. As ecological restoration and monitoring continue to be applied around the world, these types of comparative studies can be used to assess the success of habitat restoration efforts. With the addition of acoustic recording in wildlife monitoring regimes, a permanent record of biodiversity surveys can be created and used by researchers who wish to directly compare these recordings to data collected in the future. We recommend future surveys of vocalizing wildlife should include an acoustic recording component for this reason.

Our research adds to the growing body of literature highlighting the benefits that large-scale restoration and conservation projects have for biodiversity (Crouzeilles et al. 2016). It is important to recognize that tropical dry forests are particularly susceptible to impacts from climate change because species in these forests have unique life histories and breeding behaviors that strongly couple their survival and reproduction with intense seasonality (Janzen 1988a, Woodworth et al. 2018). Climate change is expected to cause more unpredictable and extreme weather, further increasing the severity of drought and fire in tropical dry forests (Miles et al. 2006). Given this, it is critically important that conservation initiatives continue to be implemented and monitored in the Neotropics. Our results showed that bird diversity and abundance were greatest in the most mature forest patches, which are thought to serve as refugia for animals seeking to escape the extreme conditions of adjacent young forests, particularly during the dry season (Janzen 1986). These refugia may become more important to wildlife as climate change continues to affect tropical dry forests.

Our results reveal the ways in which the restoration efforts in the Área de Conservación Guanacaste are successfully promoting bird community recovery. However, despite these encouraging findings, full recovery of tropical dry forests and their associated bird communities may not be reached for several centuries. Based on our results, we recommend that conservation initiatives focus on further protection of undisturbed forests and reconnecting these forest patches through habitat restoration. We also recommend continued monitoring of bird communities in the Área de Conservación Guanacaste to fill remaining gaps in our understanding of how bird communities recover in late successional forests.

\section{AUTHOR CONTRIBUTIONS}

$\mathrm{KCO}$ and DJM designed the study and wrote the manuscript. KCO collected field data with field assistance from researchers listed in the acknowledgements. KCO analyzed the audio data and conducted the statistical analyses. ADM, FAC, and LMF collected vegetation data. TWG collected 1996 point-count data. All authors contributed to editing and revising the manuscript.

Responses to this article can be read online at: http://www.ace-eco.org/issues/responses.php/1615

\section{Acknowledgments:}

We thank M. Bornais, A. Demko, C. Macfarlane, K. McGuire, L. Snobl, and K. Switzer for field assistance, R. Simpson for assistance with analyses, and R. Blanco, M. M. Chavarria, and the Área de Conservación Guanacaste for assistance and logistical support and for their dedicated work in protecting and recovering neotropical dry forest. Financial support for this research was provided by the Natural Sciences and Engineering Research Council of Canada (Discovery Grants to DJM, ADM, LMF; Equipment Grants and an Accelerator Supplement to DJM; PDF to ADM; Canada Research Chair to LMF), and by the University of Windsor.

\section{LITERATURE CITED}

Allen, W. H. 1988. Biocultural restoration of a tropical forest. BioScience 38:156-161. https://doi.org/10.2307/1310447

Allen, W. H. 2001. Green phoenix: restoring the tropical forests of Guanacaste, Costa Rica. Oxford University Press, New York, New York, USA.

Audacity Team. 2018. Audacity ${ }^{\circledR}$ : free audio editor and recorder. [online] URL: https://audacityteam.org

Baldo, S., and D. J. Mennill. 2011. Vocal behavior of Great Curassows, a vulnerable Neotropical bird. Journal of Field Ornithology 82:249-258. https://doi.org/10.1111/j.1557-9263.2011.00328. $\mathrm{x}$

Bates, D., M. Mächler, B. Bolker, and S. Walker. 2015. Fitting linear mixed-effects models using lme4. Journal of Statistical Software 67(1). https://doi.org/10.18637/jss.v067.i01

BirdLife International. 2016. Great Curassow Crax rubra. The IUCN Red List of Threatened Species. IUCN, Cambridge, UK. [online] URL: https://www.iucnredlist.org/species/22678521/92776389

Block, W. M., A. B. Franklin, J. P. Ward Jr, J. L. Ganey, and G. C. White. 2001. Design and implementation of monitoring studies to evaluate the success of ecological restoration on wildlife. Restoration Ecology 9:293-303. https://doi.org/10.1046/ j.1526-100x.2001.009003293.x

Brooks, T. M., R. A. Mittermeier, C. G. Mittermeier, G. A. B. da Fonseca, A. B. Rylands, W. R. Konstant, P. Flick, J. Pilgrim, S. Oldfield, G. Magin, and C. Hilton-Taylor. 2002. Habitat loss and extinction in the hotspots of biodiversity. Conservation Biology 16:909-923. https://doi.org/10.1046/j.1523-1739.2002.00530.x

Burivalova, Z., E. T. Game, and R. A. Butler. 2019. The sound of a tropical forest. Science 363:28-29. https://doi.org/10.1126/ science.aav1902

Buzzard, V., C. M. Hulshof, T. Birt, C. Violle, and B. J. Enquist. 2016. Re-growing a tropical dry forest: functional plant trait 
composition and community assembly during succession. Functional Ecology 30:1006-1013. https://doi.org/10.1111/1365-2435.12579

Campbell, M., and C. M. Francis. 2011. Using stereomicrophones to evaluate observer variation in North American Breeding Bird Survey point counts. Auk 128:303-312. https://doi. org/10.1525/auk.2011.10005

Carignan, V., and M.-A. Villard. 2002. Selecting indicator species to monitor ecological integrity: a review. Environmental Monitoring and Assessment 78:45-61. https://doi.org/10.1023/ A:1016136723584

Catterall, C. P., A. N. D. Freeman, J. Kanowski, and K. Freebody. 2012. Can active restoration of tropical rainforest rescue biodiversity? A case with bird community indicators. Biological Conservation 146:53-61. https://doi.org/10.1016/j.biocon.2011.10.033

Celis-Murillo, A., J. L. Deppe, and M. P. Ward. 2012. Effectiveness and utility of acoustic recordings for surveying tropical birds. Journal of Field Ornithology 83:166-179. https://doi.org/10.1111/ j.1557-9263.2012.00366.x

Chao, A. 1984. Non-parametric estimation of the classes in a population. Scandinavian Journal of Statistics 11:265-270.

Chazdon, R. L., S. G. Letcher, M. Van Breugel, M. MartínezRamos, F. Bongers, and B. Finegan. 2007. Rates of change in tree communities of secondary Neotropical forests following major disturbances. Philosophical Transactions of the Royal Society B: Biological Sciences 362:273-289. https://doi.org/10.1098/rstb.2006.1990

Chesser, R. T., K. J. Burns, C. Cicero, J. L. Dunn, A. W. Kratter, I. J. Lovette, P. C. Rasmussen, J. V. Remsen, Jr., D. F. Stotz, and K. Winker. 2019. Checklist of North and Middle American birds. American Ornithological Society, Washington, D.C., USA. [online] URL: http://checklist.aou.org/taxa

Crouzeilles, R., M. Curran, M. S. Ferreira, D. B. Lindenmayer, C. E. V. Grelle, and J. M. Rey Benayas. 2016. A global metaanalysis on the ecological drivers of forest restoration success. Nature Communications 7:11666. https://doi.org/10.1038/ ncomms11666

Darras, K., P. Batáry, B. Furnas, A. Celis-Murillo, S. L. Van Wilgenburg, Y. A. Mulyani, and T. Tscharntke. 2018a. Comparing the sampling performance of sound recorders versus point counts in bird surveys: a meta-analysis. Journal of Applied Ecology 55:2575-2586. https://doi.org/10.1111/1365-2664.13229

Darras, K., B. Furnas, I. Fitriawan, Y. Mulyani, and T. Tscharntke. 2018b. Estimating bird detection distances in sound recordings for standardizing detection ranges and distance sampling. Methods in Ecology and Evolution 2018:1928-1938. https://doi.org/10.1111/2041-210x.13031

DeLuca, T. H., G. H. Aplet, B. Wilmer, and J. Burchfield. 2010. The unknown trajectory of forest restoration: a call for ecosystem monitoring. Journal of Forestry 108:288-295.

Demko, A. D., and D. J. Mennill. 2019. Rufous-capped Warblers Basileuterus rufifrons show seasonal, temporal and annual variation in song use. Ibis 161:481-494. https://doi.org/10.1111/ ibi. 12666
Dunn, R. R. 2004. Recovery of faunal communities during tropical forest regeneration. Conservation Biology 18:302-309. https://doi.org/10.1111/j.1523-1739.2004.00151.x

Edwards, D. P., M. R. Massam, T. Haugaasen, and J. J. Gilroy. 2017. Tropical secondary forest regeneration conserves high levels of avian phylogenetic diversity. Biological Conservation 209:432-439. https://doi.org/10.1016/j.biocon.2017.03.006

Fahrig, L. 2003. Effects of habitat fragmentation on biodiversity. Annual Review of Ecology, Evolution, and Systematics 34:487-515. https://doi.org/10.1146/annurev.ecolsys.34.011802.132419

Frazer, G. W., C. D. Canham, and K. P. Lertzman. 1999. Gap light analyzer. Simon Fraser University, Burnaby, British Columbia, Canada.

Frishkoff, L. O., and D. S. Karp. 2019. Species-specific responses to habitat conversion across scales synergistically restructure Neotropical bird communities. Ecological Applications 29: e01910. https://doi.org/10.1002/eap.1910

Gillespie, T. W. 2000. Rarity and conservation of forest birds in the tropical dry forest region of Central America. Biological Conservation 96:161-168. https://doi.org/10.1016/S0006-3207(00) 00063-X

Gillespie, T. W., and H. Walter. 2001. Distribution of bird species richness at a regional scale in tropical dry forest of Central America. Journal of Biogeography 28:651-662. https://doi. org/10.1046/j.1365-2699.2001.00575.x

Janzen, D. H. 1983a. Costa Rican natural history. University of Chicago Press, Chicago, Illinois, USA.

Janzen, D. H. 1983b. No park is an island: increase in interference from outside as park size decreases. Oikos 41:402-410. https://doi. org/10.2307/3544100

Janzen, D. H. 1988a. Tropical dry forests: the most endangered major tropical ecosystem. Chapter 14 in E. O. Wilson and F. M. Peter, editors. Biodiversity. National Academies Press, Washington, D.C., USA.

Janzen, D. H. 1988b. Guanacaste National Park: tropical ecological and biocultural restoration. Pages 143-192 in J. Cairns Jr., editor. Rehabilitating damaged ecosystems. CRC, Boca Raton, Florida, USA.

Janzen, D. H., and W. Hallwachs. 2020. Area de Conservación Guanacaste, northwestern Costa Rica: converting a tropical national park to conservation via biodevelopment. Biotropica. https://doi.org/10.1111/btp.12755

Jost, L. 2006. Entropy and diversity. Oikos 113:363-375. https:// doi.org/10.1111/j.2006.0030-1299.14714.X

Kalacska, M. E. R., G. A. Sánchez-Azofeifa, J. C. CalvoAlvarado, B. Rivard, and M. Quesada. 2005. Effects of season and successional stage on leaf area index and spectral vegetation indices in three Mesoamerican tropical dry forests. Biotropica 37:486-496. https://doi.org/10.1111/j.1744-7429.2005.00067.x

Karr, J. R., and D. R. Dudley. 1981. Ecological perspective on water quality goals. Environmental Management 5:55-68. https:// doi.org/10.1007/BF01866609 
Koloff, J., and D. J. Mennill. 2013. Vocal behaviour of Barred Antshrikes, a Neotropical duetting suboscine bird. Journal of Ornithology 154:51-61. https://doi.org/10.1007/s10336-012-0867-6

Kuznetsova, A., P. B. Brockhoff, and R. H. B. Christensen. 2017. lmerTest Package: tests in linear mixed effects models. Journal of Statistical Software 82:1-26. https://doi.org/10.18637/jss.v082. i13

Latja, P., A. Valtonen, G. M. Malinga, and H. Roininen. 2016. Active restoration facilitates bird community recovery in an Afrotropical rainforest. Biological Conservation 200:70-79. https://doi.org/10.1016/j.biocon.2016.05.035

Latta, S. C., N. L. Brouwer, D. A. Mejía, and M. M. Paulino. 2018. Avian community characteristics and demographics reveal how conservation value of regenerating tropical dry forest changes with forest age. PeerJ 6:e5217. https://doi.org/10.7717/ peerj. 5217

Lefcheck, J. S. 2016. piecewiseSEM: Piecewise structural equation modelling in R for ecology, evolution, and systematics. Methods in Ecology and Evolution 7:573-579. https://doi.org/10.1111/2041-210X.12512

Matlock, R. B., and P. J. Edwards. 2006. The influence of habitat variables on bird communities in forest remnants in Costa Rica. Biodiversity and Conservation 15:2987-3016. https://doi. org/10.1007/s10531-005-4873-3

Melin, A. D., H. C. Young, K. N. Mosdossy, and L. M. Fedigan. 2014. Seasonality, extractive foraging and the evolution of primate sensorimotor intelligence. Journal of Human Evolution 71:77-86. https://doi.org/10.1016/j.jhevol.2014.02.009

Mennill, D. J., and S. L. Vehrencamp. 2005. Sex differences in singing and duetting behavior of neotropical Rufous-and-white Wrens (Thryothorus rufalbus). Auk 122:175-186. https://doi. org/10.1093/auk/122.1.175

Miles, L., A. C. Newton, R. S. DeFries, C. Ravilious, I. May, S. Blyth, V. Kapos, and J. E. Gordon. 2006. A global overview of the conservation status of tropical dry forests. Journal of Biogeography 33:491-505. https://doi.org/10.1111/j.1365-2699.2005.01424. $\mathrm{x}$

Moline, A. 1999. Tropical dry forest restoration in the Guanacaste Conservation Area, Costa Rica. Restoration and Reclamation Review 4:1-7.

Montoya, D., L. Rogers, and J. Memmott. 2012. Emerging perspectives in the restoration of biodiversity-based ecosystem services. Trends in Ecology and Evolution 27:666-672. https://doi. org/10.1016/j.tree.2012.07.004

Oksanen, J., F. G. Blanchet, M. Friendly, R. Kindt, P. Legendre, D. McGlinn, P. R. Minchin, R. B. O'Hara, G. L. Simpson, P. Solymos, M. H. H. Stevens, E. Szoecs, and H. Wagner. 2019. vegan: Community ecology package. $\mathrm{R}$ package version 2.5-6. [online] URL: https://CRAN.R-project.org/package=vegan

Orkin, J. D., F. A. Campos, M. S. Myers, S. E. C. Hernandez, A. Guadamuz, and A. D. Melin. 2019. Seasonality of the gut microbiota of free-ranging white-faced capuchins in a tropical dry forest. ISME Journal 13:183-196. https://doi.org/10.1038/ s41396-018-0256-0
Pejchar, L., T. Gallo, M. B. Hooten, and G. C. Daily. 2018. Predicting effects of large-scale reforestation on native and exotic birds. Diversity and Distributions 24:811-819. https://doi. org/10.1111/ddi.12723

Peterson, B. G., P. Carl, K. Boudt, R. Bennett, J. Ulrich, E. Zivot, D. Cornilly, E. Hung, M. Lestel, K. Balkissoon, D. Wuertz, A. A. Christidis, R. D. Martin, Z. Zhou, and J. M. Shea. 2020. Performance Analytics: econometric tools for performance and risk analysis. R package version 2.0.4. [online] URL: https://cran.rproject.org/package $=$ PerformanceAnalytics

Pillay, R., R. J. Fletcher, K. E. Sieving, B. J. Udell, and H. Bernard. 2019. Bioacoustic monitoring reveals shifts in breeding songbird populations and singing behaviour with selective logging in tropical forests. Journal of Applied Ecology 56:2482-2492. https:// doi.org/10.1111/1365-2664.13492

Quesada, M., G. A. Sanchez-Azofeifa, M. Alvarez-Añorve, K. E. Stoner, L. Avila-Cabadilla, J. Calvo-Alvarado, A. Castillo, M. M. Espírito-Santo, M. Fagundes, G. W. Fernandes, J. Gamon, M. Lopezaraiza-Mikel, D. Lawrence, L. P. C. Morellato, J. S. Powers, F. de S. Neves, V. Rosas-Guerrero, R. Sayago, and G. SanchezMontoya. 2009. Succession and management of tropical dry forests in the Americas: review and new perspectives. Forest Ecology and Management 258:1014-1024. https://doi.org/10.1016/ j.foreco.2009.06.023

R Development Core Team. 2019. R: A language and environment for statistical computing. Version 3.4.3. R Foundation for Statistical Computing, Vienna, Austria.

Ralph, J. C., J. R. Sauer, and S. Droege. 1995. Monitoring bird populations by point counts. General Technical Report PSWGTR-149. U.S. Forest Service, Pacific Southwest Research Station, Albany, California, USA. https://doi.org/10.2737/PSWGTR-149

Rempel, R. S., B. J. Naylor, P. C. Elkie, J. Baker, J. Churcher, and M. J. Gluck. 2016. An indicator system to assess ecological integrity of managed forests. Ecological Indicators 60:860-869. https://doi.org/10.1016/j.ecolind.2015.08.033

Rey-Benayas, J. M., A. C. Newton, A. Diaz, and J. M. Bullock. 2009. Enhancement of biodiversity and ecosystem services by ecological restoration: a meta-analysis. Science 325:1121-1125. https://doi.org/10.1126/science. 1172460

Robbins, C. S. 1981. Effect of time of day on bird activity. Studies in Avian Biology 6:275-286.

Roels, S. M., M. B. Hannay, and C. A. Lindell. 2019. Recovery of bird activity and species richness in an early-stage tropical forest restoration. Avian Conservation and Ecology 14(1):19. https://doi. org/10.5751/ACE-01330-140109

Santillán, V., M. Quitián, B. A. Tinoco, E. Zárate, M. Schleuning, K. Böhning-Gaese, and E. L. Neuschulz. 2020. Direct and indirect effects of elevation, climate and vegetation structure on bird communities on a tropical mountain. Acta Oecologica 102:103500. https://doi.org/10.1016/j.actao.2019.103500

Schultz, C. B. 2001. Restoring resources for an endangered butterfly. Journal of Applied Ecology 38:1007-1019. https://doi. org/10.1046/j.1365-2664.2001.00659.x 
Sekercioglu, C. H. 2012. Bird functional diversity and ecosystem services in tropical forests, agroforests and agricultural areas. Journal of Ornithology 153:153-161. https://doi.org/10.1007/ s10336-012-0869-4

Shankar Raman, T. R., G. S. Rawat, and A. J. T. Johnsingh. 1998. Recovery of tropical rainforest avifauna in relation to vegetation succession following shifting cultivation in Mizoram, north-east India. Journal of Applied Ecology 35:214-231. https://doi. org/10.1046/j.1365-2664.1998.00297.x

Shonfield, J., and E. M. Bayne. 2017. Autonomous recording units in avian ecological research: current use and future applications. Avian Conservation and Ecology 12(1):14. https://doi.org/10.5751/ ACE-00974-120114

Teixeira, D., M. Maron, and B. J. van Rensburg. 2019. Bioacoustic monitoring of animal vocal behavior for conservation. Conservation Science and Practice 1(8):e72. https://doi. org/10.1111/csp2.72

Versluijs, M., S. Eggers, J. Hjältén, T. Löfroth, and J. M. Roberge. 2017. Ecological restoration in boreal forest modifies the structure of bird assemblages. Forest Ecology and Management 401:75-88. https://doi.org/10.1016/j.foreco.2017.06.055

Walther, B. A., and J. L. Moore. 2005. The concepts of bias, precision and accuracy, and their use in testing the performance of species richness estimators, with a literature review of estimator performance. Ecography 28:815-829. https://doi.org/10.1111/ j.2005.0906-7590.04112.x

Woodworth, B. K., D. R. Norris, B. A. Graham, Z. A. Kahn, and D. J. Mennill. 2018. Hot temperatures during the dry season reduce survival of a resident tropical bird. Proceedings of the Royal Society B: Biological Sciences 285. https://doi.org/10.1098/ rspb.2018.0176

Wortley, L., J. M. Hero, and M. Howes. 2013. Evaluating ecological restoration success: a review of the literature. Restoration Ecology 21:537-543. https://doi.org/10.1111/rec.12028 
Appendix 1. Geographic coordinates of 62 sites sampled with autonomous recording units in the dry and wet seasons of 2018 and 2019 in the Área de Conservación Guanacaste, Costa Rica (latitude and longitude given in the WGS84 coordinate system).

\begin{tabular}{|c|c|c|c|c|c|}
\hline Site & $\begin{array}{l}\text { Approximate } \\
\text { forest age } \\
\text { (years) }\end{array}$ & $\begin{array}{l}\text { Dry season } \\
\text { sampling } \\
\text { date(s) }\end{array}$ & $\begin{array}{l}\text { Wet season } \\
\text { sampling } \\
\text { date(s) }\end{array}$ & Latitude & Longitude \\
\hline 1 & $>100$ & $2018-05-12$ & $2018-06-25$ & 10.85939 & -85.60964 \\
\hline 2 & 30 & 2019-04-19 & 2019-06-03 & 10.84795 & -85.60508 \\
\hline 3 & 30 & 2018-04-30 & 2018-06-16 & 10.84680 & -85.60691 \\
\hline 4 & 70 & 2019-04-19 & $2019-06-30$ & 10.84566 & -85.60782 \\
\hline 5 & 70 & 2018-05-02 & 2018-06-16 & 10.84566 & -85.61055 \\
\hline 6 & 70 & 2018-06-03 & 2018-06-16 & 10.84566 & -85.61328 \\
\hline 7 & 17 & 2019-04-13 & $2019-05-30$ & 10.83652 & -85.62420 \\
\hline 8 & 30 & 2018-04-24 & 2018-06-03 & 10.83652 & -85.62238 \\
\hline 9 & 30 & $2018-04-25$ & $2018-06-03$ & 10.83652 & -85.62056 \\
\hline 10 & 70 & 2018-04-29 & 2018-06-10 & 10.83652 & -85.61328 \\
\hline 11 & 30 & 2018-04-28 & 2018-06-11 & 10.82507 & -85.60964 \\
\hline 12 & 60 & $2018-05-07$ & $2018-06-21$ & 10.85939 & -85.61692 \\
\hline 13 & 50 & 2019-04-18 & 2019-06-01 & 10.82507 & -85.61328 \\
\hline 14 & 70 & 2018-04-29 & 2018-06-12 & 10.84110 & -85.61510 \\
\hline 15 & 60 & 2018-05-10 & 2018-06-22 & 10.84338 & -85.61601 \\
\hline 16 & 70 & 2019-04-18 & 2019-06-02 & 10.84338 & -85.61237 \\
\hline 17 & 60 & 2018-05-07 & 2018-06-21 & 10.85710 & -85.61510 \\
\hline 18 & 30 & 2018-04-28 & 2018-06-10 & 10.83423 & -85.61783 \\
\hline 19 & 5 & 2019-04-13 & $2019-05-30$ & 10.83194 & -85.62420 \\
\hline 20 & 30 & $2018-04-23$ & $2018-06-02$ & 10.83194 & -85.62147 \\
\hline 21 & 30 & 2019-04-24 & 2019-06-08 & 10.85710 & -85.60782 \\
\hline 22 & 30 & 2019-04-24 & 2019-06-08 & 10.85481 & -85.60782 \\
\hline 23 & $>100$ & $2018-05-13$ & $2018-06-25$ & 10.85710 & -85.60964 \\
\hline 24 & $>100$ & $2019-04-25$ & 2019-06-07 & 10.85481 & -85.61055 \\
\hline 25 & 60 & $2019-04-25$ & 2019-06-07 & 10.85481 & -85.61328 \\
\hline 26 & 35 & 2019-04-17 & 2019-05-31 & 10.83423 & -85.61419 \\
\hline 27 & 70 & 2018-04-30 & 2018-06-03 & 10.83881 & -85.61055 \\
\hline 28 & 30 & $2018-04-26$ & $2018-06-08$ & 10.83194 & -85.61237 \\
\hline 29 & 30 & 2018-04-24 & 2018-06-08 & 10.83194 & -85.61692 \\
\hline 30 & 30 & $2018-04-25$ & 2018-06-08 & 10.83194 & -85.61510 \\
\hline 31 & 30 & 2019-04-17 & $2019-05-31$ & 10.82965 & -85.61419 \\
\hline 32 & 30 & $2018-04-23$ & 2018-06-04 & 10.82965 & -85.61692 \\
\hline 33 & 30 & $2018-04-22$ & 2018-06-02 & 10.82965 & -85.62147 \\
\hline 34 & 60 & 2018-05-06 & 2018-06-21 & 10.85710 & -85.61874 \\
\hline 35 & 60 & $2018-05-05$ & 2018-06-19 & 10.85710 & -85.62056 \\
\hline 36 & 70 & 2018-05-02 & 2018-06-14 & 10.84338 & -85.60964 \\
\hline 37 & 30 & 2018-04-22 & 2018-06-04 & 10.82736 & -85.61601 \\
\hline 38 & 30 & 2019-04-18 & 2019-06-01 & 10.82736 & -85.61965 \\
\hline 39 & 30 & $2018-04-28$ & $2018-06-11$ & 10.82736 & -85.61237 \\
\hline
\end{tabular}




\begin{tabular}{|c|c|c|c|c|c|}
\hline 40 & 60 & 2018-05-08 & 2018-06-23 & 10.84795 & -85.61783 \\
\hline 41 & 60 & 2018-05-08 & 2018-06-23 & 10.84795 & -85.61510 \\
\hline 42 & $>100$ & $2019-04-22$ & $2019-06-06$ & 10.85024 & -85.61146 \\
\hline 43 & $>100$ & 2018-05-04 & 2018-06-15 & 10.85024 & -85.60782 \\
\hline 44 & 30 & 2019-04-21 & 2019-06-06 & 10.85253 & -85.60873 \\
\hline 45 & $>100$ & 2019-04-21 & 2019-06-04 & 10.85138 & -85.60691 \\
\hline 46 & $>100$ & 2019-04-20 & 2019-06-04 & 10.84910 & -85.60691 \\
\hline 47 & 60 & $2018-05-05$ & 2018-06-18 & 10.85253 & -85.61965 \\
\hline 48 & 60 & 2019-04-22 & 2019-06-06 & 10.85252 & -85.61238 \\
\hline 49 & 60 & 2018-05-06 & 2018-06-18 & 10.85253 & -85.61601 \\
\hline 50 & 35 & $\begin{array}{l}2018-04-12 \\
2019-04-21\end{array}$ & $\begin{array}{l}2018-05-31 \\
2019-05-28\end{array}$ & 10.83418 & -85.62372 \\
\hline 51 & 25 & $\begin{array}{l}2018-04-06 \\
2019-04-14\end{array}$ & $\begin{array}{l}2018-05-26 \\
2019-05-24\end{array}$ & 10.92188 & -85.61287 \\
\hline 52 & 70 & $\begin{array}{l}2018-04-17 \\
2019-04-09\end{array}$ & $\begin{array}{l}2018-05-30 \\
2019-05-26\end{array}$ & 10.88872 & -85.61542 \\
\hline 53 & 25 & $\begin{array}{l}2018-04-20 \\
2019-04-06\end{array}$ & $\begin{array}{l}2018-05-28 \\
2019-05-24\end{array}$ & 10.91862 & -85.61195 \\
\hline 54 & 20 & $\begin{array}{l}2018-04-25 \\
2019-04-07\end{array}$ & $\begin{array}{l}2018-05-29 \\
2019-05-23\end{array}$ & 10.95352 & -85.60473 \\
\hline 55 & $>100$ & $\begin{array}{l}2018-04-20 \\
2018-05-31\end{array}$ & $\begin{array}{l}2018-05-31 \\
2019-05-25\end{array}$ & 10.83945 & -85.61420 \\
\hline 56 & 50 & $\begin{array}{l}2018-04-20 \\
2019-04-11\end{array}$ & $\begin{array}{l}2018-05-31 \\
2019-05-25\end{array}$ & 10.95017 & -85.59703 \\
\hline 57 & $>100$ & $\begin{array}{l}2018-04-18 \\
2019-04-10\end{array}$ & $\begin{array}{l}2018-05-30 \\
2019-05-26\end{array}$ & 10.88017 & -85.61535 \\
\hline 58 & 30 & $\begin{array}{l}2018-04-26 \\
2019-04-10\end{array}$ & $\begin{array}{l}2018-05-31 \\
2019-06-02\end{array}$ & 10.87042 & -85.59830 \\
\hline 59 & 20 & $\begin{array}{l}2018-04-05 \\
2019-04-07\end{array}$ & $\begin{array}{l}2018-05-29 \\
2019-05-23\end{array}$ & 10.95185 & -85.61115 \\
\hline 60 & 40 & $\begin{array}{l}2018-04-21 \\
2019-04-12\end{array}$ & $\begin{array}{l}2018-06-01 \\
2019-05-28\end{array}$ & 10.83407 & -85.62492 \\
\hline 61 & 70 & $\begin{array}{l}2018-04-17 \\
2019-04-10\end{array}$ & $\begin{array}{l}2018-05-31 \\
2019-05-26\end{array}$ & 10.87488 & -85.60902 \\
\hline 62 & 45 & $\begin{array}{l}2018-04-19 \\
2019-04-11\end{array}$ & $\begin{array}{l}2018-05-31 \\
2019-05-25\end{array}$ & 10.83952 & -85.61802 \\
\hline
\end{tabular}


Appendix 2. Total counts of birds detected in bioacoustic surveys in the Área de Conservación Guanacaste, Costa Rica, during bioacoustic monitoring in the dry and wet season of 2018 and 2019 (some sites sampled in both years); counts are summed across sites of similar age.

\begin{tabular}{|c|c|c|c|c|c|c|c|c|c|c|c|}
\hline \multirow{2}{*}{ Scientific Name ${ }^{1}$} & \multirow{2}{*}{ Common name } & \multicolumn{5}{|c|}{$\begin{array}{l}\text { Approximate forest age in years } \\
\text { (number of surveys per group) }\end{array}$} & \multirow[b]{2}{*}{$\begin{array}{l}70 \\
(24)\end{array}$} & \multirow[b]{2}{*}{$\begin{array}{l}>100 \\
(22)\end{array}$} & \multicolumn{2}{|c|}{$\begin{array}{l}\text { Season } \\
\text { totals }\end{array}$} & \multirow{2}{*}{$\begin{array}{l}\text { Grand } \\
\text { Total }\end{array}$} \\
\hline & & $\begin{array}{l}20 \\
(20)\end{array}$ & $\begin{array}{l}30 \\
(48)\end{array}$ & $\begin{array}{l}40 \\
(8)\end{array}$ & $\begin{array}{l}50 \\
(6)\end{array}$ & $\begin{array}{l}60 \\
(22)\end{array}$ & & & Dry & Wet & \\
\hline Crypturellus cinnamomeus & Thicket Tinamou & 37 & 83 & 19 & 15 & 40 & 27 & 22 & 125 & 118 & 243 \\
\hline Ortalis vetula & Plain Chachalaca & 1 & 1 & 1 & 0 & 0 & 0 & 0 & 3 & 0 & 3 \\
\hline Penelope purpurascens & Crested Guan & 6 & 17 & 0 & 1 & 11 & 8 & 7 & 30 & 20 & 50 \\
\hline Crax rubra & Great Curassow & 0 & 0 & 0 & 0 & 0 & 1 & 6 & 4 & 3 & 7 \\
\hline Colinus cristatus & Crested Bobwhite & 7 & 3 & 2 & 0 & 0 & 0 & 0 & 6 & 6 & 12 \\
\hline Patagioenas flavirostris & Red-billed Pigeon & 7 & 21 & 1 & 4 & 19 & 19 & 13 & 43 & 41 & 84 \\
\hline Columbina inca & Inca Dove & 4 & 7 & 6 & 4 & 0 & 1 & 1 & 17 & 6 & 23 \\
\hline Columbina passerine & Common Ground Dove & 4 & 11 & 4 & 0 & 2 & 1 & 2 & 16 & 8 & 24 \\
\hline Claravis pretiosa & Blue Ground Dove & 0 & 0 & 0 & 0 & 5 & 0 & 0 & 0 & 5 & 5 \\
\hline Leptotila verreauxi & White-tipped Dove & 28 & 89 & 18 & 17 & 26 & 45 & 25 & 150 & 98 & 248 \\
\hline Zenaida asiatica & White-winged Dove & 6 & 10 & 4 & 2 & 4 & 1 & 3 & 14 & 16 & 30 \\
\hline Morococcyx erythropygus & Lesser Ground-Cuckoo & 3 & 2 & 0 & 0 & 0 & 0 & 0 & 2 & 3 & 5 \\
\hline Piaya cayana & Squirrel Cuckoo & 0 & 1 & 0 & 2 & 4 & 7 & 3 & 12 & 5 & 17 \\
\hline Trochilidae sp. & Hummingbird sp. & 0 & 11 & 0 & 3 & 5 & 3 & 4 & 13 & 13 & 26 \\
\hline Burhinus bistriatus & Double-striped Thick-knee & 0 & 1 & 2 & 0 & 0 & 0 & 0 & 1 & 2 & 3 \\
\hline Vanellus chilensis & Southern Lapwing & 0 & 5 & 1 & 0 & 0 & 0 & 0 & 5 & 1 & 6 \\
\hline Leptodon cayanensis & Gray-headed Kite & 0 & 1 & 0 & 0 & 0 & 0 & 0 & 0 & 1 & 1 \\
\hline Rupornis magnirostris & Roadside Hawk & 3 & 7 & 0 & 2 & 1 & 0 & 0 & 8 & 5 & 13 \\
\hline Trogon melanocephalus & Black-headed Trogon & 18 & 28 & 8 & 10 & 8 & 25 & 5 & 39 & 63 & 102 \\
\hline Trogon caligatus & Gartered Trogon & 0 & 2 & 0 & 1 & 1 & 7 & 1 & 7 & 5 & 12 \\
\hline Trogon elegans & Elegant Trogon & 8 & 40 & 14 & 12 & 32 & 53 & 22 & 73 & 108 & 181 \\
\hline Momotus lessonii & Lesson's Motmot & 0 & 6 & 0 & 0 & 10 & 14 & 13 & 10 & 33 & 43 \\
\hline Eumomota superciliosa & Turquoise-browed Motmot & 6 & 11 & 4 & 2 & 6 & 12 & 7 & 30 & 18 & 48 \\
\hline
\end{tabular}




\begin{tabular}{|c|c|c|c|c|c|c|c|c|c|c|c|}
\hline Notharchus hyperrhynchus & White-necked Puffbird & 0 & 2 & 0 & 0 & 1 & 1 & 2 & 4 & 2 & 6 \\
\hline Ramphastos sulfuratus & Keel-billed Toucan & 0 & 1 & 0 & 1 & 0 & 2 & 1 & 4 & 1 & 5 \\
\hline Melanerpes hoffmannii & Hoffmann's Woodpecker & 14 & 49 & 11 & 18 & 18 & 24 & 8 & 73 & 69 & 142 \\
\hline Dryocopus lineatus & Lineated Woodpecker & 0 & 0 & 0 & 0 & 0 & 0 & 2 & 0 & 2 & 2 \\
\hline Campephilus guatemalensis & Pale-billed Woodpecker & 0 & 6 & 5 & 1 & 12 & 7 & 6 & 23 & 14 & 37 \\
\hline Herpetotheres cachinnans & Laughing Falcon & 2 & 0 & 0 & 2 & 0 & 0 & 0 & 0 & 4 & 4 \\
\hline Micrastur semitorquatus & Collared Forest-Falcon & 0 & 1 & 0 & 0 & 2 & 1 & 1 & 3 & 2 & 5 \\
\hline Eupsittula canicularis & Orange-fronted Parakeet $*$ & 32 & 88 & 21 & 8 & 17 & 22 & 12 & 133 & 67 & 200 \\
\hline Brotogeris jugularis & Orange-chinned Parakeet $*$ & 13 & 44 & 5 & 14 & 77 & 37 & 21 & 106 & 105 & 211 \\
\hline Amazona albifrons & White-fronted Parrot $*$ & 6 & 33 & 5 & 8 & 15 & 6 & 4 & 32 & 45 & 77 \\
\hline Amazona farinose & Mealy Parrot $*$ & 0 & 0 & 1 & 0 & 0 & 0 & 0 & 1 & 0 & 1 \\
\hline Amazona auropalliata & Yellow-naped Parrot* & 11 & 35 & 7 & 12 & 7 & 9 & 5 & 39 & 47 & 86 \\
\hline Thamnophilus doliatus & Barred Antshrike & 0 & 5 & 0 & 1 & 18 & 24 & 24 & 40 & 32 & 72 \\
\hline Sittasomus griseicapillus & Olivaceous Woodcreeper & 1 & 6 & 0 & 2 & 9 & 6 & 11 & 22 & 13 & 35 \\
\hline Dendrocincla homochroa & Ruddy Woodcreeper & 0 & 1 & 0 & 0 & 2 & 0 & 3 & 3 & 3 & 6 \\
\hline $\begin{array}{l}\text { Dendrocolaptes } \\
\text { sanctithomae }\end{array}$ & $\begin{array}{l}\text { Northern Barred } \\
\text { Woodcreeper }\end{array}$ & 0 & 4 & 0 & 0 & 1 & 7 & 2 & 9 & 5 & 14 \\
\hline Xiphorhynchus flavigaster & Ivory-billed Woodcreeper & 2 & 14 & 0 & 2 & 13 & 8 & 12 & 19 & 32 & 51 \\
\hline Lepidocolaptes souleyetii & Streak-headed Woodcreeper & 0 & 7 & 1 & 9 & 16 & 18 & 20 & 45 & 26 & 71 \\
\hline Chiroxiphia linearis & Long-tailed Manakin & 9 & 41 & 4 & 11 & 37 & 45 & 66 & 103 & 110 & 213 \\
\hline Tityra semifasciata & Masked Tityra & 0 & 0 & 0 & 0 & 0 & 1 & 2 & 3 & 0 & 3 \\
\hline Pachyramphus aglaiae & Rose-throated Becard & 0 & 1 & 0 & 0 & 0 & 0 & 0 & 0 & 1 & 1 \\
\hline Onychorhynchus coronatus & Royal Flycatcher & 0 & 0 & 0 & 0 & 1 & 0 & 3 & 3 & 1 & 4 \\
\hline Platyrinchus cancrominus & Stub-tailed Spadebill & 0 & 0 & 0 & 0 & 0 & 3 & 2 & 1 & 4 & 5 \\
\hline Oncostoma cinereigulare & Northern Bentbill & 0 & 1 & 0 & 0 & 4 & 2 & 7 & 6 & 8 & 14 \\
\hline Poecilotriccus sylvia & $\begin{array}{l}\text { Slate-headed Tody- } \\
\text { flycatcher }\end{array}$ & 0 & 2 & 0 & 0 & 3 & 8 & 11 & 9 & 15 & 24 \\
\hline Todirostrum cinereum & Common Tody-Flycatcher & 0 & 0 & 0 & 0 & 1 & 0 & 1 & 2 & 0 & 2 \\
\hline Tolmomyias sulphurescens & Yellow-olive Flycatcher & 4 & 66 & 4 & 26 & 46 & 61 & 37 & 117 & 127 & 244 \\
\hline
\end{tabular}




\begin{tabular}{|c|c|c|c|c|c|c|c|c|c|c|c|}
\hline Camptostoma imberbe & $\begin{array}{l}\text { Northern Beardless- } \\
\text { Tyrannulet }\end{array}$ & 1 & 4 & 1 & 2 & 3 & 1 & 1 & 10 & 3 & 13 \\
\hline Myiopagis viridicata & Greenish Elaenia & 1 & 1 & 0 & 1 & 2 & 12 & 8 & 15 & 10 & 25 \\
\hline Attila spadiceus & Bright-rumped Attila & 2 & 4 & 0 & 1 & 6 & 9 & 12 & 16 & 18 & 34 \\
\hline Myiarchus tuberculifer & Dusky-capped Flycatcher & 0 & 3 & 1 & 1 & 3 & 5 & 11 & 15 & 9 & 24 \\
\hline Myiarchus nuttingi & Nutting's Flycatcher & 0 & 3 & 0 & 0 & 1 & 0 & 0 & 0 & 4 & 4 \\
\hline Myiarchus tyrannulus & Brown-crested Flycatcher & 17 & 42 & 9 & 12 & 11 & 10 & 1 & 67 & 35 & 102 \\
\hline Pitangus sulphuratus & Great Kiskadee & 2 & 5 & 3 & 1 & 1 & 0 & 0 & 8 & 4 & 12 \\
\hline Megarynchus pitangua & Boat-billed Flycatcher & 0 & 1 & 0 & 0 & 1 & 2 & 1 & 3 & 2 & 5 \\
\hline Myiodynastes luteiventris & Sulphur-bellied Flycatcher & 3 & 11 & 3 & 5 & 7 & 9 & 7 & 29 & 16 & 45 \\
\hline Legatus leucophaius & Piratic Flycatcher & 0 & 5 & 0 & 0 & 0 & 0 & 0 & 4 & 1 & 5 \\
\hline Pachysylvia decurtata & Lesser Greenlet & 0 & 24 & 2 & 8 & 18 & 26 & 25 & 43 & 60 & 103 \\
\hline Vireo flavoviridis & Yellow-green Vireo & 6 & 99 & 8 & 22 & 80 & 109 & 56 & 194 & 186 & 380 \\
\hline Calocitta formosa & White-throated Magpie-Jay & 6 & 9 & 9 & 3 & 1 & 0 & 0 & 22 & 6 & 28 \\
\hline Troglodytes aedon & House Wren & 1 & 0 & 0 & 0 & 0 & 0 & 0 & 1 & 0 & 1 \\
\hline Campylorhynchus rufinucha & Rufous-naped Wren & 35 & 95 & 22 & 27 & 43 & 54 & 16 & 149 & 143 & 292 \\
\hline Thryophilus rufalbus & Rufous-and-white Wren & 0 & 0 & 0 & 2 & 2 & 1 & 22 & 12 & 15 & 27 \\
\hline Thryophilus pleurostictus & Banded Wren & 39 & 158 & 37 & 30 & 58 & 65 & 20 & 198 & 209 & 407 \\
\hline Cantorchilus modestus & Cabanis's Wren & 0 & 1 & 0 & 0 & 4 & 8 & 11 & 14 & 10 & 24 \\
\hline Ramphocaenus melanurus & Long-billed Gnatwren & 0 & 4 & 0 & 0 & 9 & 5 & 10 & 13 & 15 & 28 \\
\hline Polioptila albiloris & White-lored Gnatcher & 3 & 35 & 9 & 3 & 0 & 5 & 1 & 33 & 23 & 56 \\
\hline Polioptila plumbea & Tropical Gnatcatcher & 2 & 9 & 1 & 7 & 28 & 35 & 19 & 61 & 40 & 101 \\
\hline Catharus ustulatus & Swainson's Thrush * & 0 & 1 & 0 & 0 & 0 & 0 & 0 & 1 & 0 & 1 \\
\hline Turdus grayi & Clay-coloured Thrush & 1 & 4 & 1 & 1 & 1 & 4 & 2 & 7 & 7 & 14 \\
\hline Euphonia affinis & Scrub Euphonia & 6 & 27 & 1 & 8 & 20 & 10 & 4 & 50 & 26 & 76 \\
\hline Peucaea ruficauda & Stripe-headed Sparrow & 1 & 6 & 2 & 0 & 3 & 0 & 0 & 3 & 9 & 12 \\
\hline Arremonops rufivirgatus & Olive Sparrow & 1 & 6 & 1 & 0 & 5 & 7 & 2 & 7 & 15 & 22 \\
\hline Icterus pustulatus & Streak-backed Oriole & 0 & 2 & 0 & 1 & 0 & 0 & 0 & 3 & 0 & 3 \\
\hline Dives dives & Melodious Blackbird & 0 & 4 & 0 & 0 & 0 & 0 & 0 & 0 & 4 & 4 \\
\hline Quiscalus mexicanus & Great-tailed Grackle & 2 & 2 & 1 & 0 & 0 & 0 & 0 & 2 & 3 & 5 \\
\hline
\end{tabular}




\begin{tabular}{lllllllllll}
\hline \hline Setophaga petechia & Yellow Warbler * & 0 & 0 & 0 & 1 & 0 & 0 & 0 & 1 & 0 \\
Basileuterus rufifrons & Rufous-capped Warbler & 6 & 38 & 4 & 6 & 41 & 33 & 19 & 67 & 80 \\
Passerina caerulea & Blue Grosbeak & 0 & 2 & 0 & 0 & 0 & 0 & 0 & 2 & 0 \\
Eucometis penicillata & Gray-headed Tanager & 0 & 1 & 0 & 1 & 1 & 0 & 1 & 2 & 2 \\
\hline
\end{tabular}

${ }^{1}$ Naming follows the American Ornithological Society's Birds of North and Middle America Checklist (Chesser et al. 2019).

* Species marked with asterisks are migratory birds ( 2 species of songbird) or highly mobile species ( 5 species of parrot) that were not included in the analyses presented in the manuscript, for reasons stated in the Methods. 
Appendix 3. Species counts from point-count surveys completed in Sector Santa Rosa of the Área de Conservación Guanacaste, Costa Rica, in 1996 and 2019, as well as differences in counts per species.

\begin{tabular}{|c|c|c|c|c|}
\hline Scientific name ${ }^{1}$ & Common name & 1996 & 2019 & Difference \\
\hline Crypturellus cinnamomeus & Thicket Tinamou & 10 & 3 & -7 \\
\hline Crax rubra & Great Curassow & 0 & 8 & +8 \\
\hline Patagioenas flavirostris & Red-billed Pigeon & 1 & 2 & +1 \\
\hline Columbina passerina & Common Ground-dove & 0 & 1 & +1 \\
\hline Leptotila verreauxi & White-tipped Dove & 5 & 10 & +5 \\
\hline Zenaida asiatica & White-winged Dove & 3 & 0 & -3 \\
\hline Piaya cayana & Squirrel Cuckoo & 7 & 4 & -3 \\
\hline Amazilia spp. & Hummingbird sp. & 5 & 3 & -2 \\
\hline Rupornis magnirostris & Roadside Hawk & 3 & 1 & -2 \\
\hline Trogon melanocephalus & Black-headed Trogon & 5 & 5 & 0 \\
\hline Trogon caligatus & Gartered Trogon & 1 & 0 & -1 \\
\hline Trogon elegans & Elegant Trogon & 7 & 9 & +2 \\
\hline Motmotus lessonii & Lesson's Motmot & 4 & 1 & -3 \\
\hline Eumomota superciliosa & Turquoise-browed Motmot & 0 & 1 & +1 \\
\hline Melanerpes hoffmannii & Hoffmann's Woodpecker & 22 & 7 & -15 \\
\hline Campephilus guatemalensis & Pale-billed Woodpecker & 2 & 1 & -1 \\
\hline Herpetotheres cachinnans & Laughing Falcon & 0 & 1 & +1 \\
\hline Thamnophilus doliatus & Barred Antshrike & 3 & 7 & +4 \\
\hline Sittasomus griseicapillus & Olivaceous Woodcreeper & 5 & 3 & -2 \\
\hline Dendrocolaptes picumnus & Northern Barred-Woodcreeper & 2 & 2 & 0 \\
\hline Xiphorhynchus flavigaster & Ivory-billed Woodcreeper & 2 & 5 & +3 \\
\hline Lepidocolaptes souleyetii & Streak-headed Woodcreeper & 1 & 2 & +1 \\
\hline Chiroxiphia linearis & Long-tailed Manakin & 7 & 16 & +9 \\
\hline Tityra semifasciata & Masked Tityra & 3 & 0 & -3 \\
\hline Onychorhynchus coronatus & Royal Flycatcher & 0 & 1 & +1 \\
\hline Oncostoma cinereigulare & Northern Bentbill & 0 & 1 & +1 \\
\hline Poecilotriccus sylvia & Slate-headed Tody-Flycatcher & 2 & 0 & -2 \\
\hline Tolmomyias sulphurescens & Yellow-olive Flycatcher & 7 & 18 & +11 \\
\hline Camptostoma imberbe & Northern Beardless Tyrannulet & 2 & 0 & -2 \\
\hline Elaenia flavogaster & Yellow-bellied Elaenia & 2 & 0 & -2 \\
\hline Attila spadiceus & Bright-rumped Attila & 0 & 1 & +1 \\
\hline Myiarchus tuberculifer & Dusky-capped Flycatcher & 27 & 4 & -23 \\
\hline Myiarchus nuttingi & Nutting's Flycatcher & 3 & 0 & -3 \\
\hline
\end{tabular}


Myiarchus tyrannulus

Megarynchus pitangua

Myiozetetes similis

Myiodynastes maculatus

Legatus leucophaius

Pachysylvia decurtata

Calocitta formosa

Campylorhynchus rufinucha

Thryophilus rufalbus

Thryophilus pleurostictus

Ramphocaenus melanurus

Polioptila albiloris

Polioptila plumbea

Turdus grayi

Euphonia affinis

Arremonops rufivirgatus

Basileuterus rufifrons

Eucometis penicillata

Cyanerpes cyaneus
Brown-crested Flycatcher

Boat-billed Flycatcher

Social Flycatcher

Streaked Flycatcher

Piratic Flycatcher

Lesser Greenlet

White-throated Magpie-Jay

Rufous-naped Wren

Rufous-and-white Wren

Banded Wren

Long-billed Gnatwren

White-lored Gnatcatcher

Tropical Gnatcatcher

Clay-coloured Thrush

Scrub Euphonia

Olive Sparrow

Rufous-capped Warbler

Grey-headed Tanager

Red-legged Honeycreeper

Total species

Total individuals

$\begin{array}{lll}9 & 4 & -5 \\ 10 & 0 & -10 \\ 1 & 0 & -1 \\ 2 & 0 & -2 \\ 0 & 1 & +1 \\ 0 & 14 & +14 \\ 11 & 0 & -11 \\ 20 & 31 & +11 \\ 0 & 1 & +1 \\ 17 & 37 & +20 \\ 0 & 4 & +4 \\ 29 & 0 & -29 \\ 0 & 5 & +5 \\ 0 & 1 & +1 \\ 0 & 2 & +2 \\ 11 & 2 & -9 \\ 16 & 21 & +5 \\ 1 & 0 & -1 \\ 2 & 0 & -2 \\ \mathbf{3 7} & \mathbf{3 5} & \mathbf{- 2} \\ \mathbf{2 6 7} & \mathbf{2 3 8} & \mathbf{- 2 9}\end{array}$

\footnotetext{
${ }^{1}$ Naming follows the American Ornithological Society's Birds of North and Middle America Checklist (Chesser et al. 2019).
} 


\section{Bird biodiversity increases as dry forests regrow in Guanacaste, Costa Rica}

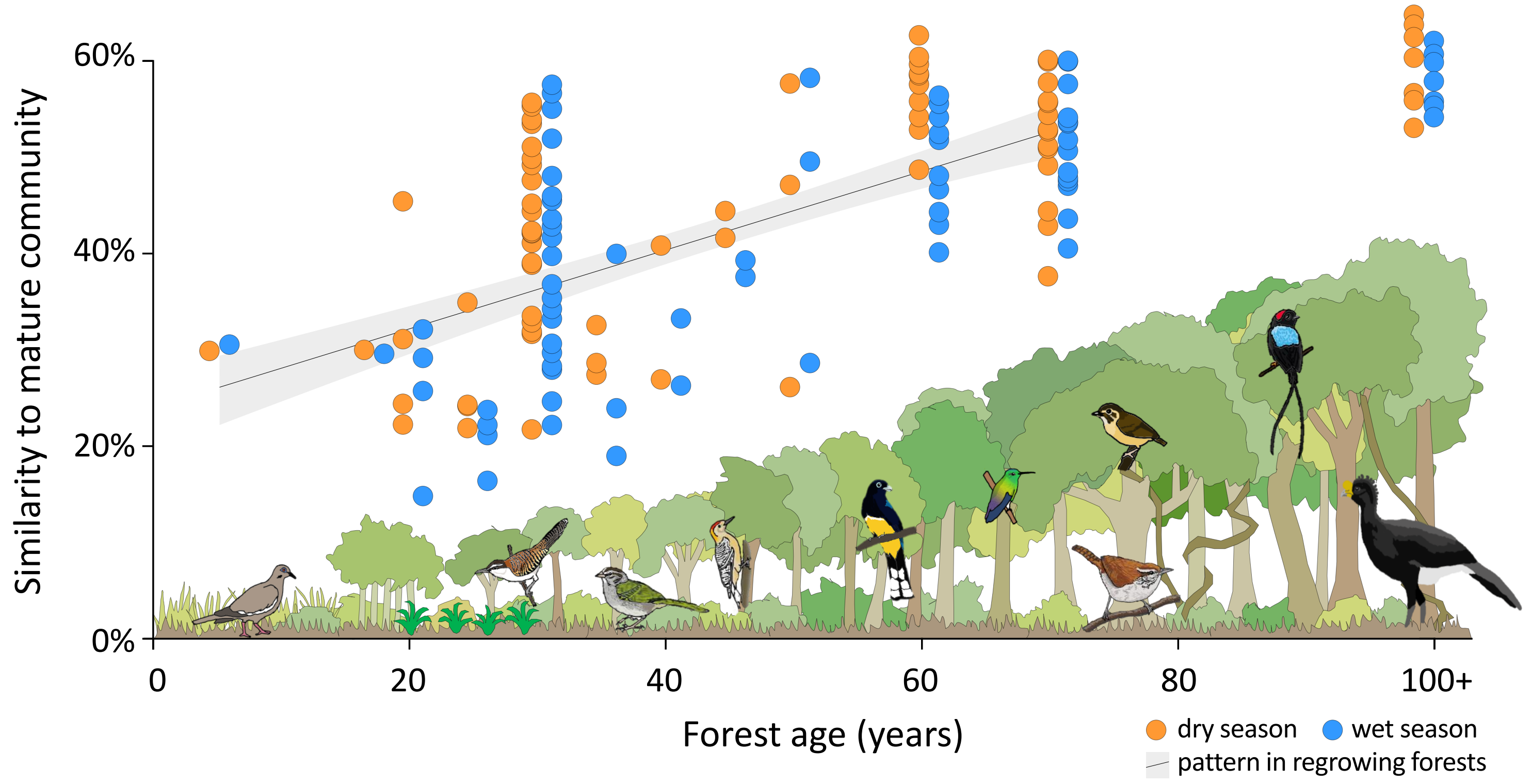

Owen, Melin, Campos, Fedigan, Gillespie, \& Mennill. 2020. Bioacoustic analyses reveal that bird communities recover with forest succession in tropical dry forests. Avian Conservation \& Ecology. 